\title{
Review: Life of Captain Cook
}

Source: The Geographical Journal, Vol. 30, No. 6 (Dec., 1907), pp. 653-655

Published by: geographicalj

Stable URL: http://www.jstor.org/stable/1776823

Accessed: 26-06-2016 20:20 UTC

Your use of the JSTOR archive indicates your acceptance of the Terms \& Conditions of Use, available at

http://about.jstor.org/terms

JSTOR is a not-for-profit service that helps scholars, researchers, and students discover, use, and build upon a wide range of content in a trusted digital archive. We use information technology and tools to increase productivity and facilitate new forms of scholarship. For more information about JSTOR, please contact support@jstor.org.

The Royal Geographical Society (with the Institute of British Geographers), Wiley are collaborating with JSTOR to digitize, preserve and extend access to The Geographical Journal 
respecting the mineral wealth of Peru, and useful hints on equipment and arrangements for journeys in the Andes.

The accounts of Incarial ruins actually visited by the author are exceedingly interesting. Chavin, as Mr. Enock truly remarks, calls for closer and more detailed examination. He gives a photograph of the very intricately carved stone of Chavin, now at Lima, upon which much has already been written, and which forms an important link in a chain of evidence. The original plate illustrates the learned paper on the stone of Chavin by Don Jose Toribio Bolo (Lima, 1900). The author's visit to the ruins of Huanuco has resulted in one of the kest existing accounts of those remarkable edifices. The ruins, with the remains of columns, at Incahuasi have already been fully described.

Mr. Enock appears to have made three other expeditions-one along the coast north of Mollendo, visiting the valleys of Camana and Ocoña; another to the famous quicksilver-mines of Huancavelica; and a third to see the gold-mines of Aporoma and Poto. In his coast journeys he gives a good description of the desert medanos, though he cannot be complimented on the illustration. His descriptions of the llocllas or fan-shaped deposits at the openings of mountain gorges, and of the appearance of an authelion, deserve attention. The journeys to Huancavelica and Caravaya appear to have been very hurried, and his more detailed reports of the mines of those regions are presumably confidential.

It is pleasant to read Mr. Enock's kindly and generous appreciation of the good qualities of the Peruvian Indians. He has a favourable word for their industry as agriculturalists, as well as for their skill in the production of textile fabrics and cleverly designed pottery. Of a poetical and imaginative habit of thought, the Indians are fond of music and of singing their love ditties and yaravies. They have good qualities, as Mr. Enock testifies, and are hospitable and faithful when their confidence is once gained.

A great part of this portly volume is occupied with extracts from works on Inca civilization, on the Amazonian Indians, and other subjects with which the author is not personally acquainted; and it was, we think, a mistake to derive all his information respecting the Incas from an author of the eighteenth century, instead of going to the original authorities, which are now easily accessible both in Spanish and English. But for the chapters containing Mr. Enock's personal observations and his own experiences we have nothing but praise.

The map which accompanies Mr. Enock's book is inaccurate, especially as regards the course of the river Paucartambo, yet no doubt it is based on the latest available information. This is one more proof of the urgent need there is for the preparation of an authoritative map of the eastern slopes of the Peruvian Andes.

\section{GENERAL.}

\section{Life of Captain Cook.}

'Captain James Cook, R.N., F.R.s., “The Circumnavigator."' By Arthur Kitson. London: Murray. 1907. Maps and 1llustrations. Price 15s. net.

The appearance, in this volume, of a connected narrative of the life of the greatest English navigator is to be heartily welcomed. Strange as it may appedr, in view of the copious literature on the subject, such an account, based on the most trustworthy first-hand documents, has never before existed, most writers having been content to copy the often inaccurate 'Life,' by Kippis, or the narratives by Hawkesworth and Douglas, which, as is well known, were interlardedespecially the former-with the personal opinions and reflections of those editors. Mr. Kitson has applied himself to all the available original sources, including 
the Admiralty papers preserved at the Record Office, and by a judicious use of published material as well, has for the first time placed in a true light the whole career of the navigator, so far as data exist for the portrayal. The amount of careful labour expended on the work must have been very great, and the author has evidently spared no pains to make the result as complete and accurate as possible. He has been able to correct in many particulars the somewhat imaginative accounts of previous writers, especially with regard to the earlier part of his hero's career. As regards the three voyages on which the navigator's title to fame must mainly rest, the actual corrections in matters of fact are not, perhaps, so numerous, or at least not so obvious, and a detailed comparison with previous narratives would be necessary to bring many of them to light. In this part of the book the author confines himself mainly to a straightforward narrative of events, and restricts the work of commentator within somewhat narrow limits. But this is a fault-if such it be-on the right side, and we at least escape the distraction of unnecessary breaks in the story.

With regard to Cook's ancestry, Mr. Kitson is inclined to think that he was of Scottish extraction, and he considers that his father must have been possessed of more education than has generally been supposed. He follows Dr. Young--the best authority for Cook's early life-in holding that the latter was never bound apprentice to Mr. Saunderson of Staithes, but that there was merely a verbal agreement without indentures. The story of the shilling stolen from his employer's till, and the running away to sea as a consequence, is shown to be quite unjust to Cook's memory, the matter having been cleared up to the satisfaction of his master, who freely abetted the boy in his aspirations after a sailor's life. Cook's entry into the Royal Navy, after his period of service with the Walkers, was, Mr. Kitson thinks, quite a voluntary act, and not the result of fear of the press-gang.

The papers in the Record Office permit us to follow with complete certainty his movements from one ship to another during the stirring times of the war with France, particularly in the operations resulting in the conquest of Canada. In the short space of two years he rose to the rank of master, the first ship to which he was appointed in this capacity (1757) being the Solebay, not the Mercury, as is usually stated. The mistake arose from the fact that there was a second James Cook in the service at this time. We do not learn much of Cook's personal work, but it is evident that he was actively and usefully employed, though the story that be piloted the troops to the landing beneath the heignts of Abraham must, it seems, be given up. With the conclusion of peace came the important surveys on the coasts of Canada and Newfoundland, and the details given throw into clear relief the whole-hearted devotion to his work which distinguished the navigator throughout his whole career.

The story of the three great voyages is told in a clear and easy style, frequent extracts from the explorer's own journals helping to bring his personality vividly before the reader. His private correspondence with the Walkers and others is drawn upon for the elucidation of certain points, while quotations from contemporary writers or official documents help to throw light on various circumstances connected with the preparations for the voyages and the estimation in which the commander was held at the time. As an instance of Mr. Kitson's thoroughness, we may mention that after quoting from Dr. Burney's 'Memoirs' a statement that Cook had marked his own route in pencil on his (Dr. Burney's) copy of Bougainville's map, he is able to inform us that the pəncil-marks on the chart (now in the British Museum) are as distinct as when they were first made. Due prominence is given to Cook's services towards the stamping out of scurvy, while the extracts relating to the organization of the third voyage, and the circumstances 
under which Cook was led to sacrifice his well-earned rest by volunteering for the command, are of particular interest. The account of the tragic end to his career does not seem to add anything to our previous knowledge, though it is useful to have the most authoritative version placed on record, when so many conflicting statements are current. It is in regard to the geographical aspects of the voyages that a somewhat fuller commentary might have been acceptable. Little attempt is made to discuss the position of geographical knowledge at the opening of Cook's career of discovery, or to sum up the total additions to such knowledge which resulted from it. While touching on the search for Bouvet island, we might have expected the author to refer to its eventual discovery, only a few years ago, by the Valdivia. He does not seem aware of the existence of the club, once in the possession of Sir J. Banks, by which Cook is said to have met his death, nor of the monument lately erected to his memory by a French admirer at Méréville. Elsewhere he shows himself fully informed on subjects of recent discussion. Thus he successfully defends Cook's claim to priority on the east coast of Australia against Cardinal Moran's fantastic theory of its discovery by Quiros. And it would be ungracious to dwell upon possible omissions, which are certainly few and unimportant, while, taken as a whole, the author has done a most creditable piece of work, for which he deserves the gratitude of all students of geographical discovery.

The illustrations are well chosen, and consist almost entirely of photographic reproductions of contemporary documents, portraits, and drawings. The two portraits of Cook are those preserved in Greenwich Hospital and in the Whitby Museum, the former by N. Dance.

\section{A Pocket-book for Travellers.}

'Scouting and Reconnaissance in Savage Countries.' By Captain C. H. Stigand, F.R.G.s., F.z.s. London: Hugh Rees, Ltd. 1907. Price 5s. net.

Under the above title, Captain C. H. Stigand has produced a little handbook, which gives a great deal of information of a very practical nature in connection with matters that cannot fail to be of importance, not only to the scout in a hostile country, but to all pioneers and explorers. To begin with, there are useful hints on finding the time and direction by means of rough bearings of the sun, stars, and moon, which, though not pretending to scientific accuracy, should be of assistance to any traveller unprovided with instruments who may be hurrying through a wild country. This is followed by a chapter on "Landmarks and General Information," another on "Tracking," which contains many good tips for following up and recognizing the spoor of various animals and men. After this follows a chapter of "General Hints," one on "Tribal Customs and Differences," followed by one on "Reconnoitring Hostile Kraals or Villages." There are also two appendices, the first of which gives instructions for using the star maps which are placed in pockets at the beginning and end of the book, while the second suggest various "Exercises for Scouts," to assist in observing and noting events, and facts that may prove of importance later on. Among the books consulted, Captain Stigand specially mentions the Society's 'Hints to Travellers,' and for more exact information on all the astronomical matters dealt with this should be referred to.

The little work is strongly bound in pocket-book form, and at the end contains blank pages for notes and for keeping a rough field book.

\section{SHORT NOTICES.}

Asia._- Wanderings East of Suez.' By Frederic C. Penfield. (London : George Bell. 1907. Pp. xvii., 349. Illustrations. 10s. 6d.net.) In part this book partakes of the character of those written by "wauderers" with no particular purpose, save 